\title{
Broad Base Biological Assay using Liquid based Detection Arrays
}

F. Milanovich, J. Albala, B. Colston, R. Langlois, K. Venkateswaren

\section{October 31, 2000}

U.S. Department of Energy

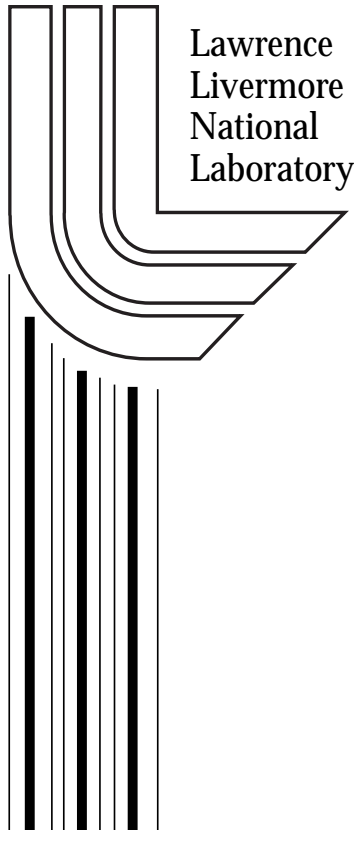




\section{DISCLAIMER}

This document was prepared as an account of work sponsored by an agency of the United States Government. Neither the United States Government nor the University of California nor any of their employees, makes any warranty, express or implied, or assumes any legal liability or responsibility for the accuracy, completeness, or usefulness of any information, apparatus, product, or process disclosed, or represents that its use would not infringe privately owned rights. Reference herein to any specific commercial product, process, or service by trade name, trademark, manufacturer, or otherwise, does not necessarily constitute or imply its endorsement, recommendation, or favoring by the United States Government or the University of California. The views and opinions of authors expressed herein do not necessarily state or reflect those of the United States Government or the University of California, and shall not be used for advertising or product endorsement purposes.

This work was performed under the auspices of the U. S. Department of Energy by the University of California, Lawrence Livermore National Laboratory under Contract No. W-7405-Eng-48.

This report has been reproduced directly from the best available copy.

Available electronically at http://www.doc.gov/bridge

Available for a processing fee to U.S. Department of Energy

And its contractors in paper from

U.S. Department of Energy

Office of Scientific and Technical Information

P.O. Box 62

Oak Ridge, TN 37831-0062

Telephone: (865) 576-8401

Facsimile: (865) 576-5728

E-mail: reports@adonis.osti.gov

Available for the sale to the public from

U.S. Department of Commerce

National Technical Information Service

5285 Port Royal Road

Springfield, VA 22161

Telephone: (800) 553-6847

Facsimile: (703) 605-6900

E-mail: orders@ntis.fedworld.gov

Online ordering: http://www.ntis.gov/ordering.htm

OR

Lawrence Livermore National Laboratory

Technical Information Department's Digital Library

http://www.llnl.gov/tid/Library.html 


\section{Broad Base Biological Assay using Liquid Based Detection Arrays \\ F. Milanovich, J. Albala, B. Colston, R. Langlois, and K. Venkateswaren}

The release of a biological agent by terrorists represents a serious threat to the safety of US citizens. At present there are over 50 pathogens and toxins on various agency threat lists. Most of these pathogens are rarely seen by public health personnel so the ability to rapidly identify their infection is limited. Since many pathogenic infections have symptomatic delays as long as several days, effective treatment is often compromised. This translates into two major deficiencies in our ability to counter biological terrorism (1) the lack of any credible technology to rapidly detect and identify all the pathogens or toxins on current threat lists and (2) the lack of a credible means to rapidly diagnose thousands of potential victims.

In this SI we are developing a rapid, flexible, inexpensive, high throughput, and deeply multiplex-capable biological assay technology. The technology, which we call the Liquid Array (LA), utilizes optical encoding of small diameter beads which serve as the templates for biological capture assays. Once exposed to a fluid sample these beads can be identified and probed for target pathogens at rates of several thousand beads per second. Since each bead can be separately identified, one can perform parallel assays by assigning a different assay to each bead in the encoded set. The goal for this development is a detection technology capable of simultaneously identifying 100 s of different bioagents and/or of rapidly diagnosing several thousand individuals.

We are pursuing this research in three thrusts. In the first we are exploring the fundamental interactions of the beads with proteins and nucleic acids in complex mixtures. This will provide us with a complete understanding of the limits of the technology with respect to throughput and complex environment. A major spin-off of this activity is in the rapidly emerging field of proteomics where we may be able to rapidly assess the interactions responsible for cell metabolism, structural organization, and DNA replication and repair. Understanding the complexities of these interactions is a fundamental step towards comprehending key aspects of disease biochemistry. This past year, using the LA technology, we were able to confirm the dynamics of a well characterized three protein, bacterial DNA repair mechanism UvrABC. Next fiscal year we will begin studying the less characterized mammalian homologous recombinational DNA repair pathway examining the protein/protein and protein/DNA interactions of RAD51B/C.

In the second thrust, we are looking at a model human disease state to assess the application of the LA in highly parallel and rapid medical diagnostics. In collaboration with researchers at UCSF and the California Department of Public Health we are developing a multiplex assay for the determination of Herpes- 8 exposure (a cancer inducing virus) in aids patients. We have successfully demonstrated a 8-plex assay and will extend to 20-plex in the near future. In a parallel effort we will develop an 18-plex assay for detecting antibodies to all vaccine-preventable childhood viral infections.

Finally we are developing a concept that would utilize the bead assay in the simplest possible form. After microbead capture of the biomarker sample and a fluorescent reporter in solution, the beads are trapped on an ordered dipstick array (Fig. 1). The color of each bead is used to identify the biomarker, while the fluorescent reporter measures its concentration. This concept, MIDS, would enable widespread use of the technology by reducing the capital 
Broad Base Biological Assay using Liquid Based Detection Arrays

F. Milanovich, J. Albala, B. Colston, R. Langlois, and K. Venkateswaren

investment required while greatly

simplifying its operation and maintenance.

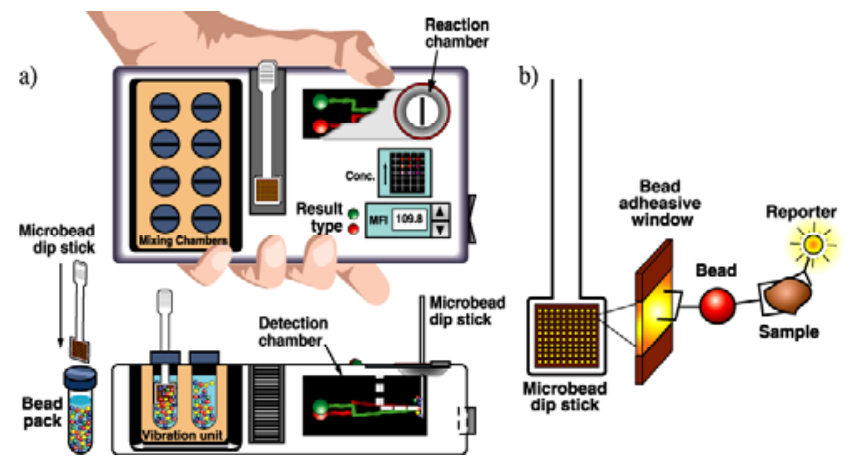

Figure 1 (a) Conceptual design for the Microbead Immunoassay Dipstick System (MIDS), where (b) sample and fluorescent molecules are trapped and detected on a disposable dipstick. 